\title{
Teachers' Professional Development: The Case of WhatsApp
}

\author{
Ramazan Cansoy $^{1}$ \\ ${ }^{1}$ Karabük University, Karabuk, Turkey \\ Correspondence: Ramazan Cansoy, Karabük University, Faculty of Letters, Department of Educational Sciences, \\ Karabük, Turkey. E-mail: cansoyramazan@gmail.com
}

Received: July 16, 2017

doi:10.5539/jel.v6n4p285

\begin{abstract}
In this study, the kinds of shares made by science teachers in a WhatsApp group as an online community of practice to support professional development were examined. The netnographic research method, one of the qualitative research methods, was used in the study. The messages shared by 12 science teachers, who worked at a private school between the years 2015-2016, in the WhatsApp group were examined in the study. Content analysis was applied to the data, and the themes were created. In the study, it was observed that teachers made shares in four different themes that support professional development. These were found to be shares for field knowledge, shares for pedagogical content knowledge, shares for in-school teaching practices and shares for emotional support among teachers. In this context, it was revealed that programs providing online chatting opportunities could be an important tool in ensuring the professional development of teachers.
\end{abstract}

Keywords: WhatsApp, online communities of practice, teacher professional development

\section{Introduction}

Online communities of practice have an important place in the sense that teachers voluntarily participate in learning, reflect their own practices to other teachers and give mutual emotional support (Macia \& Garcia, 2016). Blogs, wikis and instant messaging software help teachers to re-conceptualize and adapt information and to make information more functional (Cranefield \& Yoong, 2009). In this context, it is observed that mobile learning devices have been discussed in support of learning in recent years, along with the different opportunities offered by technology (e.g., Çakır \& Arslan, 2013; Rambe \& Bere, 2013; Hwang, Huang, \& Wu, 2011; Macia \& Garcia, 2016). However, it is stated that there is no adequate study examining the behaviours of teachers related to online communities of practice in the literature. Marcia and Garcia (2016) investigated the effects of online communities of practice on ensuring the professional development of teachers. In their comprehensive study, it is stated that the research sample is mostly focused on university students. In this regard, it is considered important to investigate the different aspects of teachers' behaviours in online learning communities. Therefore, the way the WhatsApp application, which is regarded as an online community of practice that can be used on mobile devices, is used by teachers to ensure professional development was the subject of this study.

Along with the idea of communities of practice, the fact that the internet has developed has engendered studies of "online communities of practice" (Baran \& Cagiltay, 2010). In the explanation of teacher learning, online or offline networks are addressed on the basis of communities of practice (Wesely, 2013). In this context, teachers' shares on WhatsApp that were examined in this study were addressed within the context of communities of practice. It can be stated that the WhatsApp application has become a significant alternative for learning and teaching in recent years and that sharing and communication can be made easily in this way. In this regard, teachers intensively use online learning applications within the context of professional development (Marcia \& Garcia, 2016; Cranefield \& Yoong, 2009). Communities of practice have three main features. These are field, community and practice. There is a common and well-defined field in the field community of practice. This field contributes to sharing, and at the same time, has an identity. The community dimension emphasizes the members' common activities, discussions and information sharing. Belongingness emerges along with the occurrence of community. The community of practice emphasizes the common sources created by the members as a result of their sharing, and the sharing of experiences (Wenger, 1998; Wenger, McDermott, \& Snyder, 2002). Different social networks are also addressed as communities of practice (Wesely, 2013). 
Studies of online communities of practice can be conducted through different technological tools. In this regard, it can be stated that mobile devices and smart phones have had a special place in recent years because mobile devices promote cooperative learning. In mobile learning, different contents are shared without seeking for time and place. They can also offer more effective learning and teaching activities than other media tools for communication and cooperation (Rambe \& Bere, 2013). In other words, learning arises everywhere and all the time. It can be stated that mobile learning improves learning by the fact that different theories support each other. When today's mobile learning applications are examined, it is observed that the theories used are associated with learning theories such as the Behaviorist Theory, Cognitive Theory and Constructivist Theory (Keskin \& Metcalf, 2011). On the other hand, in the literature, there are studies trying to explain the professional development of teachers within the context of sociocultural learning, communities of practice, social learning and social learning theory (Marcia \& Garcia, 2016). Sociocultural learning is an important determinant in the cooperation among teachers. In this process, it is stated that professional learning can take place by repeating, mutually sharing and modelling certain practices (Vytgosky, 1978; Van Lare \& Brazer, 2013). Accordingly, adults are regarded as social beings in the community of practice approach. They indicate that adults should be actively present in learning environments. In other words, they need social learning environments (Baran \& Cagiltay, 2010). In parallel with these statements, Brookfield (1986) points out that adults learn through collaborative studies in social environments when they work as target-oriented and think about what they have learned. According to Knowles (1990), with respect to adult learning principles, adults can direct themselves depending on their development related to learning, their experiences and knowledge provide a resource for learning, and they learn by studying and discussing different problems. On the other hand, they want to learn the things that will be useful for them, that are based on their interest, and that they will have the opportunity to implement.

There are pieces of evidence regarding the fact that there are relationships between teacher learning and practice and participation in different online communities of practice (e.g., Alakurt \& Keser, 2014; Wesley, 2013; Marcia \& Garcia, 2016; Cranafield \& Yoong, 2009). In this respect, to reveal what kind of contributions teachers make to each other's professional development through online communities of practice may provide some inferences in terms of practice. Therefore, in this study, the types of sharings of teachers in the field of sciences in WhatsApp groups can be revealed. On the other hand, this study can contribute to the expansion of the literature to understand how teachers develop each other professionally (Wesley, 2013; Marcia \& Garcia, 2016).

\section{Method}

\subsection{Research Design}

This study was designed in a netnographic research model. In the method of netnography, interaction is different from face-to-face communication, and written documents are ready and allow for participatory observation (Kozinets, 2010). Along with the change in communication technologies, researchers can conduct research in virtual environments by removing time and space constraints. In this context, netnography gives the opportunity to examine the information and the document in the environments where the information is transferred. In other words, virtual ethnography is conducted. Therefore, this study was also carried out by the netnography method (Özüdoğru, 2014). In this study, the messages shared by science teachers at a school on WhatsApp, which is a chat program on mobile devices, were accepted as the document. The data of the study include the WhatsApp posts covering a period of one year between 2015-2016.

WhatsApp is an application program on mobile devices. WhatsApp Messenger is a cross-platform smart phone messaging system that uses the existing internet data plan to connect with users' learning communities. Online interactors are made visible at a given moment and this allows for random synchronous and asynchronous calls within their social networks. Photographs, voice records and videos can be sent (WhatsApp, 2017). Technically, this program can be regarded as a social network that allows people to access different information quickly. WhatsApp enables users to make contact with everyone who has a Smartphone and an active internet connection and who downloads the application. Besides, groups can be created, people can be added and removed, and participants have equal rights in this program (Bouhnik \& Deshen, 2014). 


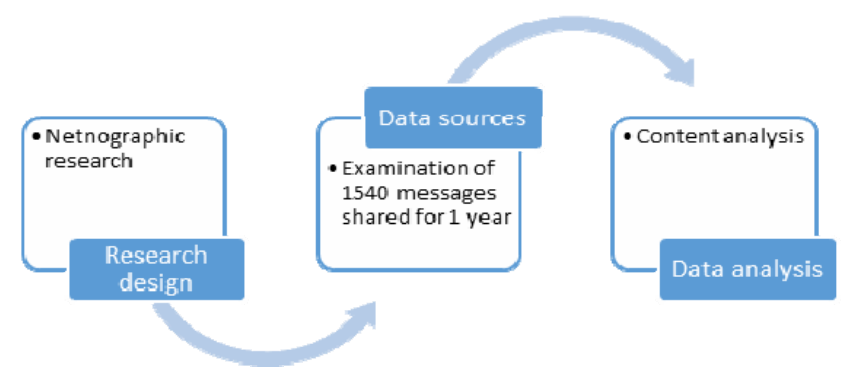

Figure 1. Schematic presentation of the research process

\subsection{Participants}

Table 1. Characteristics of preservice teachers

\begin{tabular}{lccclc}
\hline Participants & Gender & Branch & Seniority & Education & $\begin{array}{c}\text { Number of years of service at } \\
\text { this school }\end{array}$ \\
\hline P1 & M & Biology & 22 & Undergraduate & 15 \\
P2 & F & Biology & 17 & Undergraduate & 15 \\
P3 & F & Chemistry & 15 & Undergraduate & 15 \\
P4 & F & Physics & 17 & Undergraduate & 3 \\
P5 & M & Physics & 15 & Undergraduate & 3 \\
P6 & F & Biology & 5 & Undergraduate & 5 \\
P7 & M & Chemistry & 15 & Doctorate & 8 \\
P8 & F & Biology & 17 & Undergraduate & 8 \\
P9 & M & Science & 8 & Undergraduate & 6 \\
P10 & F & Physics & 17 & Undergraduate & 15 \\
P11 & F & Science & 5 & Undergraduate & 4 \\
P12 & F & Science & 5 & Undergraduate & 4 \\
\hline
\end{tabular}

According to Table 1, four of the teachers are male and eight of them are female. Four of the participants are biology teachers, two of them are chemistry teachers, three of them are physics teachers and three of them are science teachers. The seniority of teachers varies between 5 and 22 years. The average working time of teachers in this school is 8.4 years. The average seniority of teachers in the profession is 13.1 years. Mr. P1 has been serving as the head of this department for 5 years. The researcher followed the correspondences there as a participant observer. The permission required for the analysis of these talks was taken from the group. Convenience sampling was used in the selection of the study group. Convenience sampling is preferred in terms of the speed and practice of the research (Miles \& Huberman, 2015). The researcher had previously worked in this school for several years and knew the general features of the school. This school is a private school that has been serving for about 25 years and has successes in the international arena and in Turkey in different fields. This department was selected because of the successful studies of the school's science group. This group has been actively sharing through WhatsApp since 2015.

\subsection{Data Collection}

\subsubsection{Online Observations}

Observations were carried out through WhatsApp messages. No interview was held with the teachers. A total of 1540 messages were sent through this Group between September 2015 and September 2016. However, 1363 of these messages were included in the evaluation since some messages were repeated. These messages include text, sound, photographs and videos. 171 photographs or videos were shared. It was observed in the shares that photographs were sent most frequently. The remaining messages were sent as text messages. 


\subsubsection{Data Analysis and Interpretation}

In the study, content analysis was used in the analysis of WhatsApp correspondences, which were the data source. According to Patton (2002), content analysis can be regarded as an effort to reduce qualitative data aimed at basically determining the consistent aspects of the obtained large data, and to make sense of them. First of all, open coding was performed, and 58 codes were found. In this context, messages were singly read and coded. Then, two experts were authorised to review the codes, and the total number of codes was reduced to 16 . In the next step, these codes were collected under certain themes. Afterwards, the themes were put into final form and interpreted. In the study, expert opinions were consulted for reliability and validity. Two expert academicians examined the suitability of the themes. The strategies expressed by Christensen et al. (2015) were used in the validity and reliability phase of the study. (i) External control: With respect to the study, the research was reviewed by getting in touch with those who are experts in the field and who are conducting research in this field. (ii) Direct citation: The opinions of research participants and the places where the research was carried out were cited using a camera. (iii) Reviewer's assessment: Interviews were held with people with studies in the relevant field on the results of the research.

Themes are as follows: discussions on field knowledge, discussions on professional knowledge, sharing of in-school practices and shares for emotional support.

Shares for field knowledge: refers to teachers' specialized knowledge in a certain field.

Shares for pedagogical content knowledge: emphasizes how the teacher can teach what he/she knows.

Shares for in-school practices: emphasizes teachers' practices performed during their lessons.

Shares for emotional support: emphasizes that teachers support and congratulate each other for different achievements, and refers to their efforts to develop mutual trust.

\section{Results}

\subsection{Shares for Field Knowledge}

It is observed that teachers made shares related to their own branches to perform teaching. Teachers comfortably discuss the subjects and problems related to the field knowledge that they have difficulty in covering, or that they see as problematic or cannot understand with other teachers in the group. The shares can be in the form of a concept, idea, question or proof concerning a subject in the lesson. Teachers try to understand and comprehend in detail the subjects with the questions they share.

[P9]: Could you explain how setup M can be (the question is given in the next figure)? Can the weight of an object in liquid be 0 due to buoyant force?

[P5]: There are two objects in setup $M$; they weigh $4 N$ in total, but the buoyant force of the liquid can also be 2; 4-2 $=2$ can be measured. For example, it can be $1.8 \mathrm{~N}$ as the buoyant force in pot $L$ is $0.2 \mathrm{~N}$.

[P9]: In other words, the object weighing 2 Newtons can lose all of its weight in the liquid.

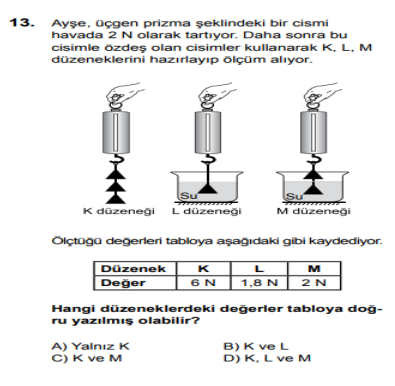

[P5]: Yes

[P9]: There is no problem in $K$ and L. Teacher, I just could not solve $M$.

[P5]: When suspended objects are weighed in the liquid, they weigh $0 \mathrm{~N}$.

It is observed that teachers discuss application-oriented projects related to their fields. These discussions can be in the form of developing a scientific project or making some technical devices related to a different field of science. Here, it can be stated that opinions are addressed with different aspects and that discussions are dealt with in different dimensions. Especially with regard to a subject discussed, it can be said that the teachers share their experience for the solution of the problems encountered and make serious efforts.

[P1]: Using hyperactive children's energy in charging the table lamp, mobile phone and tablet. How is it?

[P5]: Yes, teacher, the mobile phone can be charged. 
[P5]: If we place a battery and it charges, then we would connect the phone to it, wouldn't we? You know, rotary hand lamps, I know they always charge when you turn them periodically or aperiodically.

[P6]: About yesterday's topic. I have previously seen it in a festival. They were running the TV by pedalling like a bicycle. Like a dynamo. They are present in science museums in many countries. A science museum in Germany organized a fair in a shopping mall in Maltepe. It was also there.

[P9]: Let's put the elliptical trainers in the schoolyard, make all the lighting system led and illuminate our school; they will generate electricity downstairs during breaks; even an elective champion can be determined every month.

It is observed that teachers share the web pages they find useful to help develop their teaching subject contents from the internet. It is observed that they sometimes give detailed information about the pages shared and that they sometimes directly share the links to the pages during these shares. It is observed that the majority of teachers exhibit similar behaviours.

[P12]: There is an application called Anatomy 4D. It exists in Play Store and App Store. It looks like a useful application.

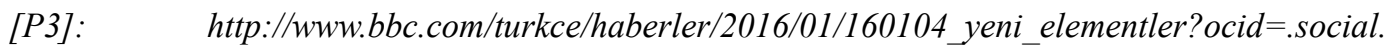
facebook.sponsored-post.AEP-Turkey-Elements.Female.Ad1.mktg

[P9]: https://youtu.be/LeqJOwo1CGo

[P2]: https://youtu.be/uKlV1L9bqWo

\subsection{Discussions on Pedagogical Content Knowledge}

There are shares regarding how teachers should behave in relationships with students and which methods they should use to reach students. It is understood from the fact that teaching principles and methods are mentioned that they also take into account the different dimensions of learning and adopt practices that include this situation in planning. Sometimes pedagogical knowledge can be expressed with a caricature, a nice statement or notes taken from different seminars or books. These expressions basically focus on how teachers should behave towards students. For example, teachers have shares about classroom management.

[P1]: A few notes from the presentation of "Being an Unshared Teacher": Teacher, please ask yourself these questions: 1) Have I created a classroom environment suitable for learning where the feeling of trust, which is the precondition of effective teaching, predominates? 2) How is my enthusiasm for teaching that will also stimulate students? Is it sound? 3) Am I using a language promising success? 4) Is my non-verbal communication motivating? (eye contact, body language, facial expressions)

[P2]: The advice given to a human being next to others is insulting, not advice... (Hz. Ali).

Teachers make shares about the planning of the teaching process, evaluation, and lesson plans. These shares consist of laboratory use or sharing of material. It is observed that teachers are in cooperation about using different teaching methods. Teachers comfortably express their opinions to improve teaching.

[P3]: Laboratory teachers, I need 3 properly running thermometers and insulating materials such as glass wool and styrofoam during course hour 3.

[P7]: Teacher, leaf test and question bank are OK, but it seems as if lecturing fascicles are incompatible with our lecture. We were pleased with the previous publications. They allowed using the book and notebook together. Now, the presentation we opened on the board and the material in the student's hand will be different.

[P1]: Write it please, I will note it. All of them, question bank, lecturing, etc.

On the other hand, it is observed that teachers try to use their critical thinking skills related to the subject within the scope of the courses and encourage each other in this direction. Studies in which critical and analytical thinking are encouraged and the subjects taught are addressed in this context are carried out. Many teachers share different practices in this regard. In other words, practices aimed at developing critical thinking in lessons are intensively discussed.

[P1]: Dear friends, I am waiting for you to set some topics in the following subjects and to evaluate them. You can create similar questions. Are environmental organizations in the world 
(Greenpeace, etc.) really environmentalist? Is it science? Is it a film? Could they be scientific lies? If you had an opportunity to clone a human being, who would you clone? Why? Does rapid population growth in the world really lead to hunger?

\subsection{Shares for In-School Teaching Practices}

It is observed that teachers take photographs or videos of the studies they perform in their own classrooms or laboratories and frequently share them in the group. Most of these shares are laboratory studies, workshop studies, seminar studies or classroom practices. With these shares, teachers learn what their colleagues are doing. For example, a teacher of a robot club can share the video of a robot while another teacher can share a photograph or video of an experiment conducted by students. Teachers' shares related to their studies are illustrated in the photographs below.
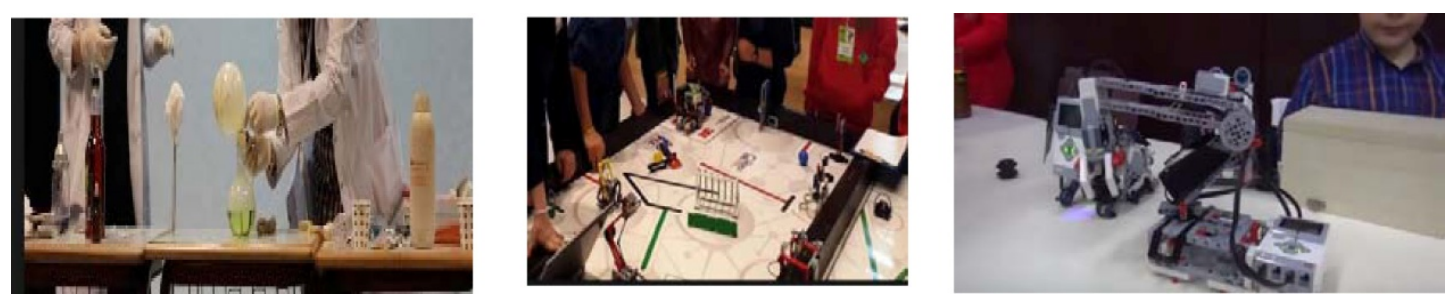

Figure 2. Examples of photographs shared by teachers

\subsection{Shares for Emotional Support among Teachers}

It is observed that teachers often congratulate and compliment each other on their achievements. It is observed that teachers attach importance to relationships and make efforts to maintain the environment of mutual trust and respect. Teachers express statements of acknowledgement and appreciation. Besides, it is observed that symbols called emoji are intensively used in these messages. These symbols are concentrated in applause, approval and hand waving. Teachers intensively support each other and emphasize it on every occasion.

[P4]: Tubitak's unmanned aerial vehicle selection result.

[P1]: Congratulations teacher, we are very happy. Its meaning?

[P2]:

[P3]: Congratulations, teacher.

[P4]: We have been entitled to take part in competition, teacher.

[P5]: I congratulate our teacher P4.

[P3]: Congratulations P4.

[P1]: Congratulations P4, I congratulate you and our students and wish you continued success.

[P8]: Congratulations, teacher. You have honored our group...

[P6]: I congratulate our teachers $P 4$ and $P 3$.

It is observed that teachers very often plan different social activities in a way to provide togetherness within the department and make shares to ensure the participation of others. For example, the breakfast program, which is one of the most organized activities within the department, is organized with those in the group, or a teacher's birthday is celebrated, and photographs or videos are shared.

[P3]: By the way, dear friends, today a morning breakfast plan for tomorrow morning emerged in the science-math group. Some of us were not in the room, let me know from here. I hope it will be a nice crowded breakfast. Today, a desire came out of my heart. We had better go to breakfast on Friday morning.

[P4]: I will come. I have no lesson.

[P3]: Please everyone, state your case, let's decide accordingly.

[P11]: I have no lesson, it will be nice. 


\section{Conclusion and Discussion}

In the study, it was observed that teachers' shares in the WhatsApp group were collected under four main themes as the shares for field knowledge, the shares for pedagogical content knowledge, the shares for teaching practices in school and the shares for emotional support.

In teachers' shares for field knowledge in the WhatsApp group, they discuss the principles and concepts within the context of the questions asked during the lesson. In other words, teachers examine a science question mutually and deeply. This allows teachers the opportunity to think deeply about principles and concepts. In their shares, teachers try to create appropriate answers to the subjects in different disciplines of science with a multiple viewpoint. In addition to these, they share computer software, useful web pages, photographs and videos related to the subject area that they can use during their lessons. With these shares, teachers also encourage each other to use technology effectively. From this point of view, it can be said that teachers make efforts to be able to use and increase the field information as required by means of their shares in WhatsApp groups. On the other side, it can be said that the other teachers in the group also increase their knowledge by following the discussions in the group.

In the WhatsApp group, teachers share pedagogical content knowledge about teaching-learning processes. It is observed that these shares are aimed at trying to motivate students, communicating with students and interacting with them. In addition to these, suggestions to provide classroom management are also shared. These suggestions are concentrated on shares such as photographs, videos and statements related to the teaching-learning process. These shares basically emphasize the answer to teachers' question of how to teach to make student learning more valuable. In this context, it can be interpreted that teachers' shares for pedagogical content make a professional contribution on how to teach.

In the WhatsApp group, teachers share photographs or videos of their own practices at school. These shares are concentrated on teachers' practices for teaching within the classroom. These shares consist of experiments conducted, and some club and workshop studies. It is observed that teachers, in this context, intensively share the practices that they perform with other teachers. The fact that teachers are informed about different practices can provide some benefits. For example, teachers can apply individual practices in their own classrooms as an example, or they can develop these practices. Furthermore, an encouraging atmosphere may emerge for teachers who see other teachers' practices.

Teachers emotionally support the others with the messages they send in the WhatsApp group, the achievements they have made or the practices they perform. It is observed that these messages are in the form of thanking, complimenting and congratulating. The fact that teachers support each other can be considered significant. The fact that students and teachers support each other at school can help the formation of a culture of trust and support. Furthermore, it can contribute to the formation of a success-oriented common vision for high standards.

According to the research findings, it can be said that online communities of practice provide a social environment in which professional development of teachers is supported. Some studies in the literature also support these results. Alakurt and Keser (2014) state that information sharing is made and that different opinions are discussed in virtual communities of practice among teachers. In his study, Rutherford (2010) expresses that social media offers teachers an encouraging, participatory, practical, collaborative and dynamic environment and helps teachers' professional development in the fields such as pedagogical content knowledge and field knowledge. It is indicated that the use of social media tools among teachers helps teachers to use knowledge by reinterpreting it (Cranefield \& Yoong, 2009). It is stated that teachers' participation in online communities of practice will encourage them to experience new methodologies, acquire new resources and think about educational theories (Marcia \& Garcia, 2016). Furthermore, these groups provide cooperation and social support in addition to enabling teachers to think about different practices (Smith Risser, 2013). Therefore, as it is understood from these statements, it can be interpreted that online communities of practice will ensure the professional development of teachers through collective practices and shared values.

This study shows that the online community of practice, which is a group among teachers on WhatsApp, supports the professional development of teachers. Therefore, it can be stated that web technologies that increase cooperation in this way are an important factor in the development of teachers. In this regard, it is possible to carry out studies aimed at creating online communities of practice in schools. In this context, it is possible to enable school administrators to help to develop online communities of practice in schools by taking the lead in this sense. 
This study was carried out with a limited group of teachers in a private school on communities of practice used on a WhatsApp program. In this context, this can be considered as a significant limitation. Therefore, this study can be carried out on different social media groups in public schools. Thus, it is possible to make examinations on how and through which shares the teachers in different groups contribute to each other's professional development. Moreover, interviews can be held with teachers to obtain more in-depth results.

\section{References}

Alakurt, T., \& Keser, H. (2014). Sanal uygulama topluluğu üyelerinin bilgi paylaşımı davranışlarının incelenmesi. İlkögretim Online, 13(4), 1331-1351.

Baran, B., \& Cagiltay, K. (2010). Motivators and barriers in the development of online communities of practice. Egitim Arastirmalari-Eurasian Journal of Educational Research, 39, 79-96.

Bouhnik, D., \& Deshen, M. (2014). WhatsApp goes to school: Mobile instant messaging between teachers and students. Journal of Information Technology Education: Research, 13, 217-231.

Brookfield, S. (1986). Understanding and facilitating adult learning. San Francisco, CA: Jossey-Bass.

Çakır, H., \& Arslan, İ. (2013). Mobil cihazlar için ders içerik paketinin geliştirilmesi. Bilişim Teknolojileri Dergisi, 6(3), 24-34.

Calvo, R., Arbiol, A., \& Iglesias, A. (2014). Are all chats suitable for learning purposes? A study of the required characteristics. Procedia Computer Science, 27, 251-260. https://doi.org/10.1016/j.procs.2014.02.028

Christensen, L. B., Johnson, R. B., \& Turner, L. A. (2015). Nitel ve karma yöntem araştırmaları. In M. Sever (Çev.), \& A. Aypay (Çev. Ed.), Araştırma yöntemleri desen ve analiz (pp. 400-433). Ankara: Anı.

Cranefield, J., \& Yoong, P. (2009). Crossings: Embedding personal professional knowledge in a complex online community environment. Online Information Review, 33(2), 257-275. https://doi.org/10.1108/14684520910951203

Hwang, W., Huang, Y., \& Wu, S. (2011). The effect of an MSN agent on learning community and achievement. Interactive Learning Environments, 19(4), 413-432. https://doi.org/10.1080/10494820903356809

Keskin, N. O., \& Metcalf, D. (2011). The current perspectives, theories and practices of mobile learning. The Turkish Online Journal of Educational Technology, 10(2), 202-208.

Knowles, M. (1990). The adult learner: A neglected species. Houston, TX: Gulf Publishing.

Kozinets, R. V. (2010). Netnography: Doing ethnographic research online. Thousand Oaks, CA: SAGE.

Macià, M., \& García, I. (2016). Informal online communities and networks as a source of teacher professional development: A review. Teaching and Teacher Education, 55, 291-307. https://doi.org/10.1016/j.tate.2016.01.021

McMillan, J. H. (2004). Educational research: Fundamentals for the consumer. Boston: Pearson Education.

Miles, M. B., \& Huberman A. M. (2015). Veri toplamaya odaklanmak ve veri toplamayı sınırlamak: Anlamlı bir başlangıç. In D. Örücü (Çev.), S. Akbaba Altun, \& A. Ersoy (Çev. Eds.), Nitel veri analizi (pp. 16-39). Ankara: PegemA.

Özüdoğru, Ş. (2014). Nitel araştırmanın iletişim araştırmalarında rol ve önemi üzerine bir deneme. Global Media Journal, 4(8), 260-275.

Patton, M. Q. (2002). Qualitative research and evaluation methods (3rd ed.). Thousand Oaks, CA: Sage Publications.

Rambe, P., \& Bere, A. (2013). Using mobile instant messaging to leverage learner participation and transform pedagogy at a South African University of Technology. British Journal of Educational Technology, 44(4), 544-561. https://doi.org/10.1111/bjet.12057

Rutherford, C. (2010). Facebook as a source of informal teacher professional development. In Education, 16(1), 60-74.

Smith Risser, H. (2013). Virtual induction: A novice teacher's use of twitter to form an informal mentoring network. Teaching and Teacher Education, 35(1), 25-33. https://doi.org/10.1016/j.tate.2013.05.001

Van Lare, M. D., \& Brazer, S. D. (2013). Analyzing learning in professional learning communities: A conceptual framework. Leadership and Policy in Schools, 12(4), 374-396. https://doi.org/10.1080/15700763.2013.860463 
Vygotsky, L. S. (1978). Mind in society. Cambridge, MA: Harvard University Press.

Wenger, E. (1998). Communities of Practice: Learning, Meaning, and Identity. Cambridge: Cambridge University Press. https://doi.org/10.1017/CBO9780511803932

Wenger, E., McDermott, R., \& Snyder, W. (2002). Cultivating communities of practice: A guide to managing knowledge. Boston, MA: Harvard Business School Press.

Wesely, P. M. (2013). Investigating the community of practice of world language educators on Twitter. Journal of Teacher Education, 64(4), 305-318. https://doi.org/10.1177/0022487113489032

WhatsApp. (2017). Retrieved from https://www.whatsapp.com/features

\section{Copyrights}

Copyright for this article is retained by the author(s), with first publication rights granted to the journal.

This is an open-access article distributed under the terms and conditions of the Creative Commons Attribution license (http://creativecommons.org/licenses/by/4.0/). 